\author{
Ana Vukmanović \\ ana.vukmanovic@hotmail.com
}

\title{
Svadbeni kod u basmama
}

\begin{abstract}
Vukmanović Ana, Svadbeni kod u basmama (The Wedding Code in Incantations), „Poznańskie Studia Slawistyczne” nr 3, Poznań 2012. Adam Mickiewicz University Press, pp. 187-200. ISBN 978-83-232-2473-0. ISSN 2084-3011.

Incantations use the wedding code in order to fulfill the magical function which faces a cure or a protection, demanded by certain people. Thus the wedding code applied to the incantation turns out to be different from the wedding song itself. The phenomena of anti-speach (insults directed to the bride or to the wedding guests) and of inverse reality of the sacred moment in the incantations become the powerful means against diseases and evil spirits. While modulating the wedding ritual objects (wedding shirt, wreath, veil, flag), or ritual actions (giving gifts, repulsing the wedding guests, taking the bride away from her parents' house), these objects and acts gain a secondary, magical function that makes diseases and evil spirits drive away. The wedding songs and the incantations share the same model of space in which forest and water introduce themselves as the strong boundaries between two worlds: of the living and of the dead. While in the first case the boundaries are porous, allowing an interpenetration of both the worlds, in the second one they remain closed off. The above mentioned genres also share some motifs - of a fast growing girl, hospitality (as well as of an uninvited guest) and magical counting. Furthermore, the article proves that various functions determine essentially different meanings of motifs, ritual actions and eventually characters which appear in these folklore genres.
\end{abstract}

Keywords: incantation, wedding song, wedding code, magical function, magical speach

Basme izgrađuju osoben svet na granici ljudskog i onostranog. To čine različitim sredstvima i različitim kodovima. Iako je funkcija basmi praktična - magijska i isceliteljska - one se van konteksta tajnog i individualnog izvođenja mogu posmatrati kao poetski tekstovi ${ }^{1}$. U takvoj poziciji one unutar folklornog sistema uspostavljaju veze sa drugim folklornim žanrovima. Upotrebljavajući svadbeni kod, bajanja se posebno približavaju obrednim pesmama.

\footnotetext{
${ }^{1}$ љ. Раденковић, Народна бајања, Београд 1983, str. 6.
} 
Moguće je uspostaviti poetičku relaciju između basmi i svadbenih pesama. Dok su prve magijski tekstovi obrazovani poetskim sredstvima, druge postoje na granici obreda i književnosti. Zavisno od toga u kolikoj je meri obred živ i koliko se pesme poklapaju sa njegovim verbalnim kodom, one funkcionišu kao ritualni tekstovi formirani poetskim sredstvima ili poetski tekstovi nastali modelovanjem ritualne stvarnosti. Pesme mogu imati i magijsku funkciju, ali se ne mogu na nju svesti. Među lirskim pesmama pozicija magijskih činova zavisi od konteksta - oni zauzimaju dominantno mesto ili se remodeluju u lirski obrazac.

Basme koriste svadbenu simboliku jer ona ujedinjuje simbolike plodnosti i umiranja ${ }^{2}$. Svadbeni kod basmi razlikuje se od lirskih predstava svadbe. U bajanjima je on sredstvo potrebno da bi se ostvario magijski cilj. Usmene pesme svadbu modeluju kao primarni član strukture kada su pesme samostalni segment prakse, kao sekundarni element slike obredno-magijskog kompleksa pojedinih obrednih pesama prolećnog ciklusa, stilizovanu (izmenjenu) kosmogoniju mitoloških pesama, metaforičnu oznaku bliskog/suprotnog obreda prelaza (smrti), kao i periferni motiv neobrednih (ljubavnih) pesama ${ }^{3}$.

Baje se u markiranom vremenu isterivanja nečiste sile (najčešće pre izlaska sunca, posle njegovog zalaska ili u ponoć) kada se spajaju suprotnosti - dodiruju se noć i dan, tama i svetlo, staro i novo ${ }^{4}$. Svadbene pesme se pevaju tokom svadbe, a doba zalaska i izlaska sunca vezuju za kretanje svatovske povorke. Pošto je reč o liminalnoj obrednoj grupi, njoj odgovara da se kreće tokom liminalnog vremena. Samo svadbeno vreme je, kao obredno i sveto, granično, ali je, usled razvijene solarne simbolike, dominantno dnevno. Međutim, lirske pesme unutar svog složenog temporalnog modela poznaju i motiv noćne svadbe: „Што би било јесенас; / нека буде вечерас, / дођи дико па ме проси, / па ме кући носи" žanra podrazumevaju sakralni kontekst.

\footnotetext{
${ }^{2}$ Idem, Народна бајања код Јужних Словена, Београд 1996, str. 140.

3 А. Вукмановић, Значења и функиије гранище у свадбеној усменој лирици, докторски рад у рукопису, Београд 2012, str. 56.

${ }^{4}$ Ibidem, str. 174.

${ }^{5}$ С. Бошковић, Бачванске песме, Нови Сад 1879 , II, $17^{\circ}$. U radu ce se pesme navoditi tako što će iza broja pod kojim se ona nalazi u zbirci stajati kružić umesto skraćenice br.
} 
Basme koriste svadbeni temporalni kod jer je svadbeno vreme važno za bajalicu koja se „zavenčava” s basmom. Kao jako vreme početka, ono se može izjednačiti s mitskim trenutkom kosmičkog stvaranja i ima snažan magijski potencijal. Svadba uspostavlja iskonski kosmički red u kom je izvršena i trajna podela između ljudi i sveta demona divljine ${ }^{6}$.

Osnovna - magijska - funkcija basmi određuje i njihov jezik. On je hermetičan jer čuva magijske tajne i moći. Često nema jasno izdiferencirano leksičko značenje, pa van konteksta može ličiti na igru rečima. Ipak, tekst je delotvoran samo ako se doslovno ponovi. I svadbene pesme poznaju hermetične formule, ali su one vremenom izgubile sakralnost.

Za obrednu i magijsku situaciju zajednička je mogućnost inverzije binarnog para. Svet ostaje polarizovan: bajalice divlje i opasno teraju iz ljudskog u neljudski prostor, čime štite čoveka. Međutim, u svetom vremenu, bilo obreda bilo bajanja, uspostavlja se privremeni izokrenuti poredak. Unutar para sinotnjica/jutrošnjica voda doneta uveče ima negativna značenja. U svadbi se ona nalazi na strani mraka, tame i obredno nečistog. Mladoženjina majka treba da se raduje jer više neće piti „синотьицу натруњену труњем и пеленом", već će joj snaha donositi ,jутрошњицу натруњену смиљем и босиљем", $\mathrm{U}$ basmama sinotnjica dobija pozitivna magijska svojstva: „Запали се Цариград... / Угаси га бајалица / са синоћну водицу...”. Pošto je vezana za noć, doba u kome su duhovi posebno aktivni i prisutni u vodama, ona ima izuzetna lekovita svojstva, koja joj daju upravo ta bića, u drugim, svakodnevnim, prilikama toliko opasna ${ }^{9}$.

Lirske, lirsko-epske pesme i balade poznaju inverzije rodnih uloga. Devojka postaje aktivna kada mami momka. Momkova majka joj poručuje: „А бора ти, јадиџар дјевојко! / Не мами ми сина јединога, / јер тако ми бора зеленога, / начинићу дворе јаворове, / око двора посадит стоборје, / у дворе ћу сина затворити / нек ми сједи у мермер авлији"10. Nasuprot uobičajenoj slici ugrožene devojke, modeluje se predstava ugro-

${ }^{6}$ Љ. Раденковић, Народна бајања код..., str. 176.

${ }^{7}$ В.Ст. Караџић, Српске народне пјесме, т. І, Београд 1975, $76^{\circ}$.

${ }^{8}$ Љ. Раденковић, Народне басме и бајања, Ниш-Приштина-Крагујевац 1982, $467^{\circ}$.

${ }^{9}$ A. Vukmanović, Voda u obredno-mitskom kontekstu narodne lirike, magistarski rad u rukopisu, Beograd 2008, str. 14.

10 „Босанска вила” бр. 17, 1896, str. 277. 
ženog momka. Obrednom izolacijom se štiti nejaki momak od moćne devojke. Ona ima moć nad dva prostora - nad divljinom i nad pitomim belim dvorima; može da preleti preko granice, preko zelenih borova, i sleti u zatvoreni prostor kuće koji ovom prilikom postaje muški. Savladavanje dva suprotstavljena sveta - unutrašnjeg i spoljašnjeg - omogućavaju devojčine medijalne moći koje ona zadobija kao granično biće unutar obreda prelaza (svadbe).

Basme, shodno svojoj funkciji, devojku koja začara momka prikazuju iz drugačije perspektive. Ako se devojci baje da bude lepa i voljena, onda su čini koje će baciti na momka poželjne: „Што ти туда јечиш? / Одговара липи (Але): / Не питајте седмери свати / (...) Ето тамо липе (Ајке), / у брдо ме узела, / у нити ме уплела; / брдом ме збија, / све ми моје кости слива" ${ }^{\text {"11 }}$. Iako se Ale žali na to što ga je Ajka savladala, kontekst pokazuje drugačiju psihološku perspektivu. Devojci se želi, i više od toga - baje se da se želja ostvari, da ovlada momkom. Dok ručni rad, tkanje, kao lirski motiv predstavlja ponovljenu kosmogoniju i dokaz ovladavanja stvaralačkim moćima, u basmi je on magijska radnja. Dolazi do usložnjavanja semantičkog polja - ručni rad može biti kosmogonijski čin, svadbeni zadatak, svakodnevna radnja, ali i magijski postupak ${ }^{12}$.

Modelujući svadbene obredne predmete, basme ih transformišu u magijske. Unutar paralelizma između ispraćanja neveste i ispraćanja bolesti (proboda), javlja se motiv svadbene košulje: „Посеја лан, лан на Видов-дан, / изниче лан, лан на Видов-дан, / обра лан, лан на Видов-дан, / (...) Саши' кошуљу лан, лан на Видов-дан, / обуко кошуљу лан, лан на Видов-дан" "3. Коšulja je važan deo spreme jer je poseban nevestinski dar mladoženji. Ona sabira devojačke moći predenja i tkanja, odnosno kosmičke stvaralačke moći, kao i kulturne odlike unutar para odeven/neodeven. Basma aktivira sakralno vereme praznika i magijsko kondenzovano vreme. Materijal od kog je sašivena košulja takođe je markiran. Lan se

11 љ. Раденковић, Народне басме и бајања, 574

${ }^{12}$ Hatidža Krnjević ostatke basme za dobar ishod devojačke sudbine nalazi u pesmi broj 44 iz Erlangenskog rukopisa. Završno venčanje devojke i cara pokazuje kako se magija neodoljive lepote na jednom nivou koristi za stvaranje sveta, a na drugom za uspostavljanje bračne veze. Х. Крњевић, Руковет лирских песама Ерлангенског рукописа, „Прилози за књижевност, језик, историју и фолклор”, књ. 42, св. 1-4, 1976, str. 123.

13 љ. Раденковић, Народна бајања код..., $34^{\circ}$. 
često koristi u bajanjima ${ }^{14}$. Interesovanje za njega pokazuju i lirske pesme koje prate mimičke radnje oponašajući sejanje, zalivanje i branje biljke ${ }^{15}$. Pojavljivanje lana u basmama i redukovanim lirskim „tekstovima” svedoči o njegovom magijskom potencijalu. Darovana svadbena košulja može biti postavljena i u središte sukoba: u Ženidbi Maksima Crnojevića nevesta ne dozvoljava da se „od zlata košulja” ustupi Milošu, jer onaj ko dobije košulju ima pravo na devojku, u Zaručnici Laza Radanovića oko čudesne košulje se zavade majka i kćer - majka je želi za sina, devojka za verenika. Prava vrednost obrednih predmeta leži u tome što su oni metonimijske zamene onih koji ih koriste/daruju ${ }^{16}$. Basma čoveku u lanenoj košulji, šreći semantičko polje, obezbeđuje zaštitu (od proboda).

Bajanja svatove modeluju kao antibića ili bolesti. Iako različiti od učesnika obreda, svatovi u basmama nose barjak, kao simbol svatovske povorke tokom kretanja od jedne kuće do druge ${ }^{17}$ : „Испратићу моје љуте ране, / оне ће бити кумови / оне ће барјак донести" ". Barjak tako postaje osnova veze između dva sveta. Svatovi u basmi moraju ujedno biti različiti od ljudskih svatova i očuvati sličnost s njima. Krećući se po granici između dva sveta, bajalica može da komunicira sa oba, da istera zle sile iz jednog u drugi. Ako ne postoji prelaz, ovom prilikom predstava svatova, odnosno svadbeni kod, ne može doći do izlečenja od prišta. Svaka komunikacija zahteva postojanje zajedničkog koda, zato, iako izmenjeni, modelovani po principima poetike basme, svatovi moraju biti prepoznatljivi. Prišt se prikazuje kao nešto poznato, nešto iz ljudskog sveta da bi se s njim moglo opštiti. Barjak je u rukama kumova-prišteva obredni predmet koji obezbeđuje upravo taj komunikacioni (i magijski) minimum potreban za delotvornost basme.

Odnos svadbenih pesama i svadbenog koda basmi prati se i unutar odnosa svadbenog dara i antidara. Poređenje motiva ženidbe vilinog sina

${ }^{14}$ O lanu videti više u: Љ. Раденковић, Слика света у народној магији Јужних Словена, Београд-Ниш 1996, str. 240-251 і В. Чајкановић, Вуна и лан, u: idem, Сmудије из религије и фолклора 1910-1924, Београд 1994, str. 428-431.

15 A. Vukmanović, Voda..., str. 26.

${ }^{16}$ А. Вукмановић, Значења и функиије границе..., str. 157.

17 Р. Иванова, Свадба као систем знакова, „Кодови словенских култура” год. 3, бр. 3,1998 , str. 10 .

${ }^{18}$ љ. Раденковић, Народне басме и бајања, 204º 
u svadbenoj mitološkoj pesmi i basmi pokazuje na koji način različiti folklorni žanrovi modeluju obredni predmet. Akter basme može da pošalje uroke i zazore kao svadbeni dar vilinom sinu: „Што се оно на прозорље виђа? / Оно вила сина жени / и мене на пир зове. / Ја јој немам с чиме

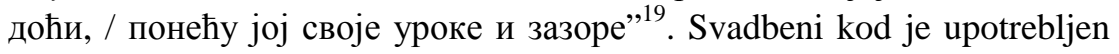
s ciljem da oslobodi čoveka zlih čini (ili da ga od njih zaštiti). Vilinska svadba nije, kao u usmenoj lirici, refleks mitske svadbe, nije ni mitska ni umetnička predstava, ona je sredstvo za ostvarenje jasnog zadatka. Funkcija dara nije mito-poetska već magijska i zaštitna. On ne uspostavlja veze između dva bića ili dve porodice, već raskida veze između demonskog i ljudskog sveta. Darivanje urocima i zazorima nemoguće je u lirici, ali je očekivano u basmi ${ }^{20}$. Junak mitološke pesme vilinom sinu daruje čudesni prsten: „Кад вила сина жењаше, / за кума мене стављаше, / ја вили прстен даровах, / у прстен небо и облак, / а вила мене кошуљу" 21. Darujući vilinskog mladoženju, lirski junak potvrđuje svoje izuzetne moći jer, kao nebotvorac, u prsten zatvara nebo i oblak. Uzdarje je košulja „,тања од пера макова”, „беља од крина из горе”. Dar se realizuje na dva nivoa: na magijskom antidar (uroci) postupkom snižavanja postaje delotvoran (bajalica otera uroke), na mitskom se uzdizanjem obrazuje predstava čudesnog predmeta (vilinska košulja, prsten). I svadba u basmi i ona u mitološkoj pesmi odvijaju se u graničnim prostorima: prva na prozoru, kao međi otovrenog i zatvorenog, druga između neba i zemlje. Naizgled jača granica između kosmičkih planova propustljivija je od one koja razdvaja ljudski svet od demonskog. Poetika basme zahteva da granice budu nepropusne jer se na taj način štite ljudi. Nasuprot tome, poetika usmene lirike omogućava komunikaciju između neba i zemlje izgrađujući mitsku predstavu isprepletenih svetova koji čine kosmičko jedinstvo. Ovo poređenje pokazuje složenost bogatog semantičkog i simboličkog potencijala svadbenog koda.

Nevesta je u svatovskim pesmama, kao biće na granici, istovremeno moćna i ugrožena. S jedne strane ona vlada moćima bilja (njime leči ili

\footnotetext{
${ }^{19}$ Ibidem, $516^{\circ}$.

${ }^{20}$ А. Вукмановић, Значења и функиије гранище..., str. 99.

${ }^{21}$ В.Ст. Караџић, Српске народне пјесме из необјављених рукописа, т. I, Београд $1973,106^{\circ}$.
} 
utiče na njegov brz rast), može da namami momka, spasava momka iz vode, ovladavajući ručnim radom ponavlja kosmogonijski čin, ubija zmiju kao mitsko čudovište. S druge strane ona mora poštovati propisane tabue osvrtanja, govorenja, dodirivanja tla, otkrivanja kose i lica, povratka ${ }^{22}$. Basme neobičnu poziciju devojke modeluju motivima brzog sazrevanja i sposobnosti savladavanja zlih čini i bolesti: „Родила се усовка девојка / синоћ по вечеру. / (У) глуво доба / про'одила и провревила, / за одадбу стигла. / Док свануло, / усов растурила, / како росу по ливаде, / како девојке по сабори, / како лис' по гору"23. Devojka je obeležena noćnim trenutkom rođenja. Taj dodir s noćnim, htonskim silama, kao i čudesni brzi rast, omogućavaju joj da rastera bolesti. Njen brz rast - to što se rodila, prohodala i dospela za udaju istog dana - predstavlja vid antiponašanja ${ }^{24}$. Antiponašanje, sposobnost snalaženja u izokrenutom poretku, u svetu na granici i u oba sveta (ljudskom i demonskom), obezbeđuje joj uspešnu borbu sa onostranim silama.

Nasuprot poželjnom brzom rastu devojke iz basme, lirika insistira na postepenom sazrevanju. Momak se ne ženi dok ne dođe vreme: „Чек ме мајко, милена, милена, / док приспије шеница, шеница, / и винова лозица, лозица, / мојој Мари сазрену, сазрену, / у њедарца јабуке, јабуке, / и док Мара приправи, приправи, / за сватове дарове, дарове",25. Devojka se menja u biološkom i kulturnom smislu - rastu joj grudi i sprema darove, odnosno ovladava veštinama stvaranja. Momkovo odrastanje dato je posredno - dok sazrevaju devojka i jesenji plodovi, sazreva i on. Budući mladenci postaju ,slika i prilika”.

Basme, poput lirskih pesama, modeluju motiv gostoprimstva. Gost može biti otelovljenje božanstva, pa se njemu na rapolaganje stavlja žena iz kuće. Na taj način se božanstvo vezuje za porodicu, a u kući se zadržavaju njegove moći i plodnost ${ }^{26}$.

Lirske pesme obred gostoprimstva transformišu u svadbeni obred. Pesma počinje stihovima: „Каd пођемо у ложницу, / Ружичица душек

${ }^{22}$ O liminalnoj poziciji neveste unutar svadbenog obreda videti više u: А. Вукмановић, Значења и функиије границе..., str. 136-150.

${ }^{23}$ Љ. Раденковић, Народне басме и бајањ $а, 177^{\circ}$.

${ }^{24}$ Idem, Народна бајања..., str. 11.

${ }^{25}$ В.Ст. Караџић, Српске народне пјесме, т. V, Београд $1898,519^{\circ}$.

${ }^{26}$ В. Чајкановић, op. cit., str. 149. 
старе, / Љубичица јорган старе, / Гонџе Ана са мном легне "27, a završava: „Ружичицу запросисмо, / Љубичицу загледасмо, / Гонџе Ану одведосмо". Prolazeći kroz inicijacijsko sjedinjenje s natprirodnim, Ana ulazi u separacionu fazu obreda prelaza, iz koje će izaći kao devojka spremna za udaju - buduća nevesta. Ložnica postaje centar i sakralni oslonac sveta jer je mesto svetog sjedinjenja. Ona će to ostati i tokom prve bračne noći, kada se na ljudskom planu obavlja sveta svadba.

U basmi su gosti bolesti (bube u glavi), a ne božanstvo: „Власи, власи - средомаси! / Ви сте бели, па сте црноглавасти, /па имате три младе невесте, / па три ноћи све једну љубите. / Ако сте бели / у бело дрво идете...,28. U odnosu na obred postupak je inverzan: dok ljudi obredom gostoprimstva pokušavaju da zadrže božansku moć unutar kuće, basmom teraju štetne sile iz kuće. I broj tri i noćno doba basme jače markiraju nego pesme, jer je njihovo magijsko značenje izraženije. Oba koitusa su sakralna, ali imaju sasvim oprečne funkcije. Dok je junakinja pesme za noć provedenu s gostom nagrađena poželjnim brakom, neveste iz basme su privremena žrtva bolesti - izložene su joj nakratko da bi se obezbedilo konačno ozdravljenje.

Kao što se bolesti teraju u poseban prostor belog drveta, tako se teraju i u daljinu. Motiv udaje na daleko basme koriste da bi na daleko oterale bolesti: „Зажени се д’л'к младожења, / па запроси далкињу девојку, / (...) / Запроси ју - испроси ју. / Оро игра / песен пеше, / свирке свираше, / пушке пуцаше, / па одоше у нем'чке земље, / преко нем'чке висине, / преко нем'чке низине, / там се растурише" 29 . Reč je o demonskoj svadbi - mladoženja i mlada su muški i ženski lik (potkožne ili stomačne) bolesti. Njihova svadba liči na ljudsku, jer se na njoj igra i peva, ali se zatim odlazi u daleku zemlju koja je markirana kao nem'čka, što znači nema. Za razliku od mladoženjine zemlje, gde odlaze mladenci na kraju obreda, koja iako nevesti tuđa, iz muške perspektive ostaje ovostrana, prostor u kom nema glasa predstavlja demonski svet. Basme za teranje nečistih sila često pominju prostore gde pas ne laje, mačka na mauče, petao ne kukuriče, jagnjad ne bleji... svi ti prostori bez zvuka alterniraju s bezglasnom zemljom.

\footnotetext{
${ }^{27}$ В.Ст. Караџић, Српске народне пјесме, т. V, $515^{\circ}$.

${ }^{28}$ Љ. Раденковић, Народна бајања.., $3^{\circ}$.

${ }^{29} \mathrm{Idem}$, Народне басме и бајањ $а, 200^{\circ}$.
} 
Basme i svadbene pesme dele zajednički pogled na svet. On određuje i model prostora, zajednički obema folklornim vrstama. Dva tipična liminalna prostora - vodu i goru - i basme i svadbene pesme modeluju kao daleke, divlje, opasne. To su mesta na koja bajalica tera zle sile, ili teško premostive svadbene granice. Isterane iz bolesnika u mutnu vodu ili u čarnu goru, bolesti odlaze u svoj, neljudski svet. Iz njega ne treba da se vrate. Lirski prikaz sistema granica: „Пратише Смиљу браћа до горе чарне, / до горе чарне, до воде ладне; / најмлађи братац за гору зађе, / за гору зађе сеју не нађе" ${ }^{30}$ odgovara formuli basme u „goru u vodu”. Devojka uspeva da izađe iz liminalnog sveta i uđe u mladoženjin. Brat, pak, zalazi u goru kao najistaknutije mesto pri konstituisanju međuprostora, ali ne nalazi sestru, niti može da je vrati staroj kući jer to obred ne dozvoljava. Nevesta je prešla granicu posle koje povratka nema. Gora je ekvivalent sveta mrtvih. Izašavši iz nje, devojka se ponovo rodila ${ }^{31}$. Basme jasno određuju goru - iz nje izlaza nema. Bolesti oterane u goru se ne vraćaju, dok i devojka i njen brat iz gore mogu izaći - svako na svoju stranu, ka svom svetu, svom domu.

Prelazeći vodenu ili gorsku granicu, mladenci, tokom liminalne faze obreda, ulaze u neljudski svet, ali oni su samo privremeno obeleženi kao onostrani, samo privremeno (obredno) umiru za svoju zajednicu da bi se ponovo rodili u novom socijalnom statusu tokom obreda agregacije. Učesnici obreda su unutar graničnih zona i ljudska i onostrana bića, dok bolesti i zle sile uvek potpuno pripadaju demonskom svetu.

Pozicija gore i vode se menja u basmama ,da devojka bude lepa i voljena" i postaje sasvim bliska onoj iz svedbenih pesama. Devojka moli Boga da joj pošalje suđenika: „Да ми ноћас дође, / да заједно соли и хлеба вечерамо, / а сјутра вјенчанице кошуље кројимо. / Ако је пре'о горе / - ево му ножа нека је расјече; / ако је пре'о воде / - ево му кашика, нека се превезе; / ако је пре'о поља / - ево му српа нека раскоси",32. Ona obezbeđuje magijske predmete i omogućava momku da tokom htonskog noćnog vremena savlada otvoreni, opasni prostor. Funkcija basme nije da otera zle sile, nego da dovede do udaje simbolizovane venčanim košuljama. Kako se menja funkcija, menja se i odnos prema

\footnotetext{
30 3. Карановић, Народне песме у Даниии, Нови Сад-Београд 1990, $48^{\circ}$.

${ }^{31}$ А. Вукмановић, Значења и функиије гранище..., str. 226-227.

32 Љ. Раденковић, Народне басме и бајања, $576^{\circ}$.
} 
prostornom modelu, koji se prilagođava žanru i kontekstu izvođenja. Da bi se devojka udala, gora, voda i polje moraju postati prohodni, odnosno, mladoženji kao biću iz drugog sveta mora se obezbediti prolaz.

Lirska junakinja omogućava mornaru da pristane tako što mu daruje vesla i jedra: „Ја ћу тебе весла дати, / б’јеле руке ђевојчине, /... Ја ћу тебе једро дати, / б'јеле скуте ђевојчине "33. Magijsku moć devojke jača sposobnost transformacije, s tim što je ona u ljubavnoj pesmi pre metaforička nego mitska. Ona svojim telom, a ne magijskim ili obrednim predmetima, zauzdava morsku stihiju, omogućava barci da pristane, a momku da dođe do nje $\mathrm{e}^{34}$.

Pošto su funkcije basmi i svadbenih pesama različite, oprečan je i njihov odnos prema mostu. Basma „od straha” naglašava nestalnost mosta i glasi: „Кад се устали на листу кап / а на мору мост / онда на теби страва" ${ }^{\text {, }}$. Svadbene pesme i bajke postavljaju zadatak građenja mosta kao težak, ali ostvariv. Nevestin otac postavlja uslov: „Мајка даје, те даје, / а ја не дам, те не дам; / док не зида ћуприју / од свог двора до мога / од камена мермера, / и бисером поткити: / кад је стану водити, / нека камен звекеће, / нека бисер трепеће" 36 . I car iz bajke o zmiji mladoženji ima istovetan uslov: „Даћу ја за твога сина девојку, ако начиниш ћуприју од мога двора до твога од бисера и драгог камења"37. Lirska pesma i bajka predstavljaju savladavanje stihije kao kosmogonijski čin, koji podrazumeva organizaciju sveta, pretvaranje haosa u kosmos. Mladoženja ili njegova majka, zauzdavajući vodu, postaju kulturni junaci. Neimenovani graditelj basme nije uspešan, jer to i ne treba da bude - cilj basme je da magijom reči otera strah. Nemogući most na moru poetska je slika podređena jasnom magijskom cilju.

Poetici basme posebno pogoduje to što svadbeni obred poznaje ritualno odbijanje svatova pred mladinom kućom. Taj postupak može dobiti sekundarnu funkciju teranja bolesti: „Пође ветар да се жени. / Он пође, али му не даду, / враћају га у планину, / у планину под зелену јелу. / Под јелом седи расплетена (Мара), / они хоће нашу (Мару). / Ми (Ма-

\footnotetext{
${ }^{33}$ В.Ст. Караџић, Српске народне пјесме, т. V, 391.

${ }^{34}$ А. Вукмановић, Значења и функиије границе..., str. 168.

${ }^{35}$ Љ. Раденковић, Народне басме и бајања, $496^{\circ}$.

${ }^{36}$ В.Ст. Караџић, Српске народне пјесме, т. I, 578 .

${ }^{37}$ Idem, Српске народне приповетке, Београд 1969, $9^{\circ}$, str. 101.
} 
py) не дамо. / Они отишли и више се не вратили" ${ }^{\text {". }}$. Za razliku od lirskog, svadbenog odbijanja koje je dato iz muške perspektive i vodi konačnom zadobijanju devojke: „Ми ћемо доћи да је просимо. / Ви ћете доћи, ми је не дамо. / Богме ћеш дати, и наша бити. / Док свекар дође, сукњу донесе. / Свекар ће доћи, сукњу донети. / Док рабар дође, прстен донесе. / Рабар ће доћи, прстен донети. / Док девер дође, венац донесе. / Девер ће доћи, венац донети" ${ }^{39}$, ono u basmi je magijsko i konačno a ne obredno. Svaki naredni stih lirske pesme približava svatovsku povorku devojci, jedan obredni predmet se unutar obredno-poetske transformacije pretvara u drugi, a svatovi se samo privremeno zadržavaju ${ }^{40}$. Basma ne dozvoljava približavanje, jer svatovi nisu ljudi, koji su iako tuđi poželjni, već bolesti (vetrovi) od kojih treba izlečiti bolesnika i doslovno ih odbiti. Naglašava se htonska simbolika planine i korena jele nasuprot ljudskoj, iako momku stranoj i tuđoj, devojčinoj kući pred kojom se odbijaju svatovi.

Antiponašanje svatova basme posebno ističu pomoću magijskog antigovora: „Јаника усов заженила / па запросила девојку Усовију, / па позвала сватови: / криво, / немо, / глуво, / ћораво, / криво не оди, / немо не збори, / глуво не чује, / ћораво не види" ${ }^{\text {"41 }}$. Vređajući bolesti, predstavljajući ih kao slabe, bajalica im magijski oduzima demonsku snagu. Analogan postupak pokazuju lirske pesme u kojima mladoženjina porodica kudi nevestu oduzimajući joj tako njene moći: „Tri se leta počesala nisi, / četiri se umivala nisi. / Kad se jesi počela česati, / tri tovara češlja potrgala; / kad se jesi počela umivat, / celu Kupu vode zamutila, / ni na pol se umivala nisi!"42. Kao neočešljana i neumivena nevesta pripada neljudskom svetu kao i usovi. Ona se postavlja u dvostruku poziciju drugosti i kao snaha/tuđa, i kao prljava/onostrana ${ }^{43}$. Iako je treba zauzdati, mlada iz

38 љ. Раденковић, Народне басме и бајања, $110^{\circ}$.

${ }^{39}$ В.Ст. Караџић, Српске народне пјесме, т. I, $1^{\circ}$.

${ }^{40}$ А. Вукмановић, Значења и функције границе..., str. 28.

${ }^{41}$ Љ. Раденковић, Народне басме и бајања, $165^{\circ}$.

${ }^{42} \mathrm{~V}$. Žganec, Hrvatske narodne pjesme kajkavske, Zagreb 1950, $300^{\circ}$.

${ }^{43}$ Kada u narodnoj igri nevestina porodica kudi nevestu: „Узели сте, ал’ нисте пробрали. / Узели сте прељу - неткаљу, / Узели сте ткаљу - непраљу, / Узели сте праљу нешваљу, / Узели сте шваљу - непрељу, / узели сте нерадну девојку”. Т. Ђорђевић, Српске народне игре, „Српски етнографски зборник” 1907, str. 185, onda pokude imaju 
svadbene pesme pripada ljudskom svetu, a onostrana je samo privremeno. U basmi je svadba prividna, a bolesti zaista i sasvim pripadaju demonskom svetu.

Osim uvredama, svatovi se zauzdavaju i tako što ih pred mladinom kućom prebrojavaju: „Редом, редом, кићени сватови, / по тројица кола испрежите; / по двојица коње раседлајте; / а по један у совру седајте; / да ве види девојачка мајка; / да ве види девојачки отац" "44. Basme dodatno markiraju postupak brojanja kada broje unazad naglašavajući smanjenje broja svatova-bolesti: „Зажени се камена девојка, / па дојдоше камени сватови, / камени девери, / камене пунице, / камене старојке, / камене з'лве. / Девет дојдоше, / осам осташе, / осам дојдоше, / седам осташе / (...) / Једна дошла, / једна отишла" ${ }^{, 45}$. Odbrojavanje pripada inverznom svetu basme. Takvo, obrnuto u odnosu na ljudski svet, blisko je demonskom svetu gde se bolesti teraju i kome one pripadaju ${ }^{46}$. Kada bajalica koristi izokrenuti postupak, ojačava svoju poziciju prema bolestima. Bori se protiv njih njihovim sredstvima.

Basma gradi motiv nepozvanog gosta: „Руса-труса сина заженила, / све је красте на свадбу позвала, / сестру Ружу неје позвала. / А она је љуто куне: / О, да бог да, Русо-трусо, / из вр' се искрутила, / из корен се исушила, / ту вечер не дочекала" ${ }^{47}$. Aktivira se očekivana obrnuta pozicija basme u odnosu na ostale folklorne žanrove. Za razliku od bajke tipa Uspavane lepotice kada nepozvana vila naudi princezi, u basmi nepozvana gošća naudi rusi (krasti). Zato što nije pozvala sestru na demonsku svadbu, krasta će se sasušiti i otpasti do večeri. Iz perspektive bolesti nepozvani gost je opasan, iz ljudske on nosi izlečenje. Isprepletenost ovih tački gledišta čini svet basmi složenim, a magijsko-poetske tekstove i estetski

sasvim drugu funkciju. One brane od uroka kom su posebno izložena izuzetna, vredna i lepa bića, kao i bića na granici. Ako je devojka neradna, nije dobra ni za uroke.

44 А. Ласек, Граница у народној поезији Јужних Словена (на материјалу свадбених песама), Нови Сад 2005, str. 13.

45 љ. Раденковић, Народне басме и бајања, $259^{\circ}$.

${ }^{46}$ Basme takođe prebrojavaju svatove, kako to čini i svadbena pesma, samo je onda njihova onostranost slabije izražena. Ovakav postupak koriste basme koje obezbeđuju devojačku sreću, gde lustrativna i apotropejska funkcija nisu izražene u istoj meri kao u onima za teranje zlih sila. Njihova pozicija je bliža svadbenoj: „Отуд иду седмери свати, / осмера племена, / деветера рода”. љ. Раденковић, Народне басме и бајања, 574.

${ }^{47}$ Ibidem, $153^{\circ}$. 
vrednim. Oni na taj način prikazuju svet kao složen i dinamičan prostor borbi suprotstavljenih sila.

Specifičnost prikaza svatova u basmama predstavlja atribucija „kameni". Ovaj atribut je pogodan jer je kamen medijator u komunikaciji s nebeskim i podzemnim bićima i kao takav omogućava opštenje bajalice i bolesti. Dodir čoveka s kamenom i osećaj hladnoće ovaploćenje su dodira s divljim i nepoznatim svetom do kog dolazi tokom bajanja ili, pre toga, pri susretu čoveka i nečiste sile, što je uzrok bolesti ${ }^{48}$.

Pomenuti motiv brzog sazrevanja devojke kombinuje se s motivom kamene neveste čime se dobija oksimoronski spoj plodnosti i neplodnosti: „Синоч се роди Раденица девојка; / од сутра дођше камени сватове / да носе камену девојку. / Носише и однеше" ${ }^{\text {"49 }}$. Sličan mehanizam temporalne kondenzacije poznaje usmena lirika. Rast devojke u lirici ipak nije toliko ubrzan, ona prati godišnji ciklus bilja: „Не плачи, Јано, заово! / Када су мене гледали, / онда су вишње сађене; / када су мене просили, / онда су вишње цватиле; / када су мене водили, / онда су вишње зобане" ${ }^{, 50}$. Rast kamene devojke sasvim je drugačiji od sazrevanja za udaju devojke koja se poredi s višnjom (ili varijantno s dunjom). U prvom slučaju rast je demonski i jalov, u drugom je usklađen sa životvornim kosmičkim principom. Kamena devojka je rođena noću, pa je i na vremenskom planu suprotstavljena devojci povezanoj sa prolećnim zrenjem prirode.

Basme konstruišu čitav jedan kameni svet. On se modeluje personalnim i lokativnim kodom: „Добро јутро, бољо! / Колико то било јутро, / толико ти ту било места. / На камен села, / с камена јела, / с камена ручала, / с камена вечерала, / с камена се удала, / камен ти кола била, / камени волови, / камен вођевина, / камен ђувегија, / камен кум, / камен стари сват, / камен сви сватови" 51 . Basma ovom prilikom aktivira značenje malog kamena, skučenog mesta na koje treba svesti bolest. Redukcija prostora vodi nestajanju bolesti. Druga odlika kamena omogućava analogiju između okamenjenog sveta i okamenjene bolesti. Atribucija predstavlja magijski postupak, sredstvo u borbi protiv demonskih sila.

\footnotetext{
${ }^{48}$ O simbolici kamena videti u: Љ. Раденковић, Народне басме и бајања, str. 113.

${ }^{49}$ Ibidem, $169^{\circ}$

${ }^{50}$ В.Ст. Караџић, Српске народне пјесме, т. I, $414^{\circ}$.

51 Љ. Раденковић, Народне басме и бајања, $207^{\circ}$.
} 
Mladini unutar svadbenog obreda postavljaju kamenje na put svatovima da bi im otežali pristup devojci ${ }^{52}$. Svadbene pesme izokreću ritualnu situaciju - kamene prepreke se ne pominju na putu ka devojačkoj kući, već pri povratku mladoženjinom domu: „А што су ти, стари свате, / потни коњи, а трудни јунаци? / Камење смо разбијали / пут чинећи Будљанци ђевојци" ${ }^{\circ 3}$. Ovakva transformacija potencira divljinu (kameniti predeo) a ne postavljanje prepreka. Određujući prostor kao neljudski, basme obezbeđuju okamenjavanje bolesti. Lokativna veza s demonskim svetom ne uspostavlja se po principima opozicije divlje/pitomo, već okamenjeno/živo. Binarni parovi se unutar mitskog sistema mišljenja mogu posmatrati kao izomorfni ${ }^{54}$, ali ne i potpuno sinonimni.

Odnos basmi i svadbenih pesama uspostavlja se svadbenim kodom. Međutim, funkcije ovih folklornih žanrova, kao i kontekst u kom se izvode, utiču na to da su značenja zajedničkih motiva, obrednih predmeta, obrednih radnji, kao i učesnika obreda/likova basmi i pesama različita. Složenost odnosa ukazuje na složenost celokupnog folklornog sistema i mnogobrojna značenja koja on u sebe inkorporira, a zatim aktivira zavisno od potrebe, a shodno mogućnostima individualne improvizacije i pravilima poetike istovetnosti.

${ }^{52}$ M. Lang, Samobor. Narodni život i običaji, „Zbornik za narodni život i običaje Južnih Slavena” knj. 18, sv. 1, 1913, str. 114.

${ }^{53}$ В.Ст. Караџић, Српске народне пјесме, т. I, $87^{\circ}$.

${ }^{54}$ M. Lotman, Ogledi iz tipologije kulture, „Treći program Radio Beograda” god. 6, br. 4 , 1976, str. 487. 